\title{
Production and Marketing of Chili in the Brong-Ahafo Area of Ghana
}

Marcella Vigneri, Shashidhara Kolavalli, John Agandin, and Qondi Moyo 


\section{TABLE OF CONTENTS}

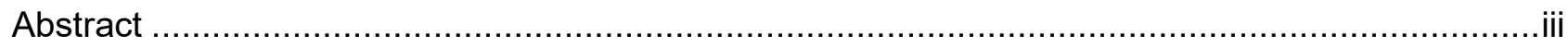

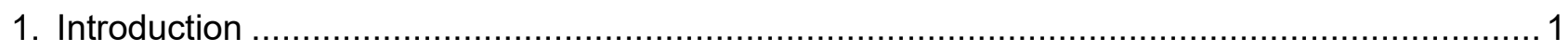

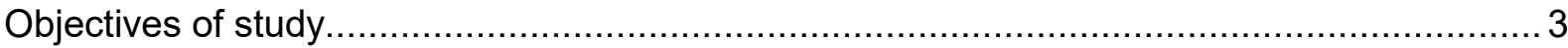

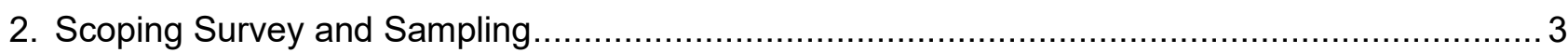

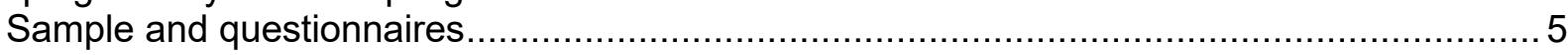

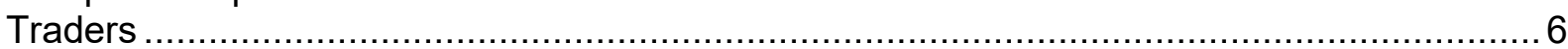

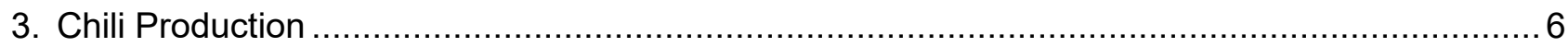

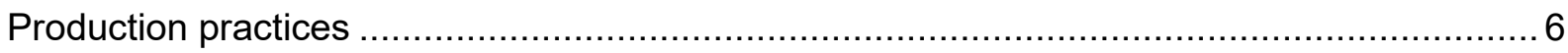

Econometric model of long chili production in Ghana ................................................. 9

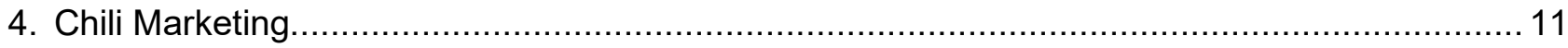

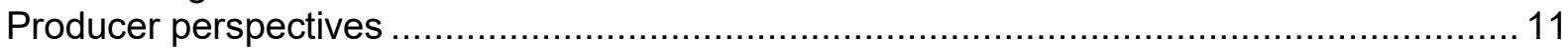

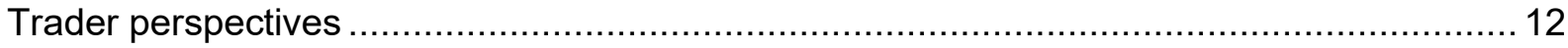

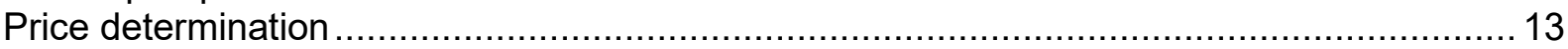

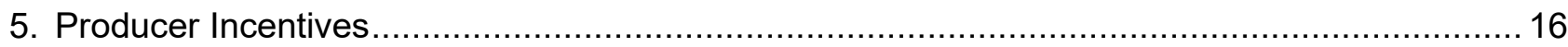

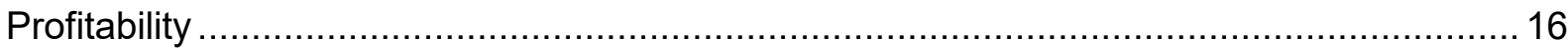

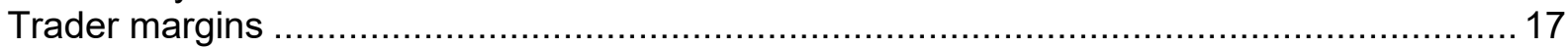

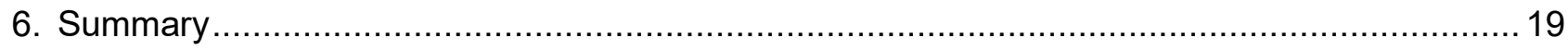

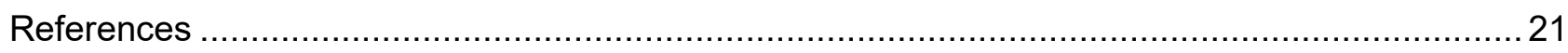

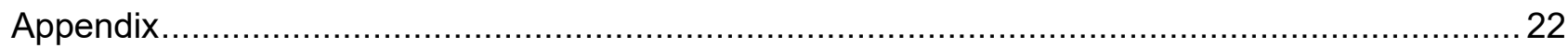

\section{LIST OF TABLES}

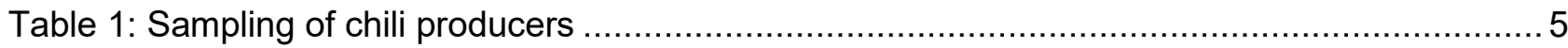

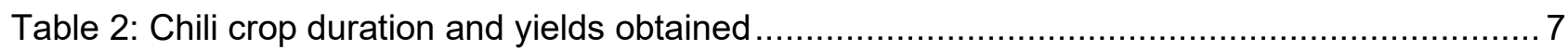

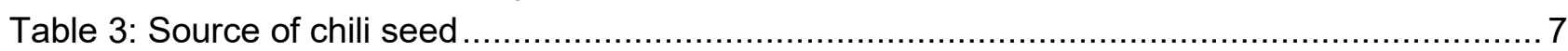

Table 4: Labor use in long chili production ...................................................................... 7

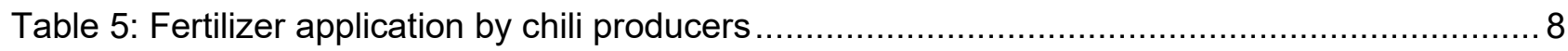

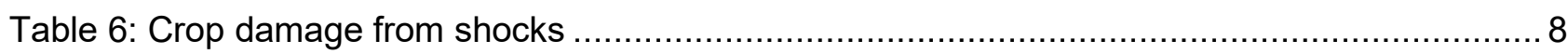

Table 7: Descriptive statistics for variables in long chili production function estimation ................. 9

Table 8: Production function estimates for long chili (dry) producers......................................... 10

Table 9: Sources of chilies for traders, share of traders using source ...................................... 12

Table 10: Descriptive statistics of variables used in the chili price determinants models .............. 14

Table 11: Ordinary Least Squares (OLS) estimates of price determinants model ...................... 15

Table 12: Gross margins from production of dry long chilies, $\mathrm{GH} \phi$ per ha ................................ 17

Table 13: Conversion of units of measure used along the chili value chain ................................ 18

Table 14: Prices and margins in selected dry long chili transactions reported by traders, grouped by quantity unit conversion in transaction ............................................................ 19

Table A1: Number of chili traders reported by producers to be operating in the communities

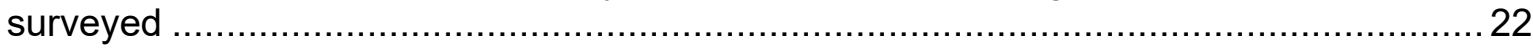

Table A2: Wholesale and retail prices per bag observed over three weeks in selected markets. .. 23

\section{LIST OF FIGURES}

Figure 1: Annual chili production in Ghana from 1991 to 2014 .............................................. 1

Figure 2: Chili in Ghana, area under cultivation, 1991 to 2014 ................................................. 2 


\section{ABSTRACT}

This paper provides an in-depth account of the chili value chain in the Brong Ahafo area of Ghana, looking at the agronomic practices of producers, marketing choices by chili type, and practices of traders along different commercial corridors.

Using original survey data of producers and traders, the paper addresses two questions: Are there opportunities to increase the productivity of chilies? Does the marketing system deliver a significant share of the consumer prices to producers?

Chili yields are less than $1.0 \mathrm{mt} / \mathrm{ha}$ against a yield potential in Ghana of nearly $8 \mathrm{mt} / \mathrm{ha}$. Long chili growers in the top 10 percentile by yields harvested nearly 18 bags compared to the average of 11 bags per acre obtained by all producers. These higher chili yields resulted primarily by applying higher levels of inorganic fertilizers. Many producers have adopted improved chili varieties - nearly 70 percent of long chili producers reported having planted Legon 18, the variety which is generally used for making chili powder. Producers also reported maintaining their crop in the field for unusually long periods to extend their production into leaner production periods.

Prices vary geographically by day and by marketing channel. The margins earned by traders on the sale price of their chilis range from 20 to 100 percent under different conditions. The chili value chain is short. The bulk of chilis produced reaches consumers with only one intermediary between producer and consumer. Fresh and dry chilies are marketed differently. Nearly 80 percent of dry chili producers sell at their farm gate, where they tend to obtain prices that are higher than those received by producers who take their dry chilies to markets. The reverse is true for fresh chili producers, however. It is plausible that producers choose between producing dry long or fresh round chilies depending on their marketing ability. Social networks influence the choice by producers of what traders to engage with, suggesting that producers with stronger ties to traders obtain higher prices. 


\section{INTRODUCTION}

Chili is an important vegetable crop in Ghana, second only to tomato. Ghanaians consume chili widely in fresh, dried, or processed forms - it is found in nearly all indigenous dishes. Estimates from the 2012/13 Ghana Living Standards Survey (GLSS) are that households spent 12.8 percent of their total food expenditures on vegetables, of which share 10 percent was expended on chilies. An estimated one million households found in almost every region of Ghana produce chili, but the bulk of it comes from producers in Brong-Ahafo, Northern, Central, Ashanti, Eastern, and Volta regions (GSS 2014). About 70 percent of chilies are produced under rainfed condition.

Information from the FAO and the Ghana Ministry of Trade and Industries (MOTI) suggests that Ghana produced an estimated 116,690 metric tons (MT) in 2013, close to the MOTI estimate of consumption at 116,670 MT (Van Asselt, Masias, and Kolavalli 2018). Another study puts production in 2012 at 110,000 MT(Saavedra Gonzalez et al. 2014). Chili generally was produced on a small scale to meet domestic requirements until around 1995 when larger scale production began for exports. Annual production levels over nearly 25 years show a significant rise in 1996 followed by a decline beginning in 2004 (Figure 1). Between 1995 and 2004, production of chili almost tripled from 114,000 to $329,000 \mathrm{MT}$, but dropped to $172,000 \mathrm{MT}$ in 2009 , with a substantial decline particularly in fresh chili production. Saavedra Gonzalez et al. (2014) attribute the decline to reductions in irrigated production.

Figure 1: Annual chili production in Ghana from 1991 to 2014

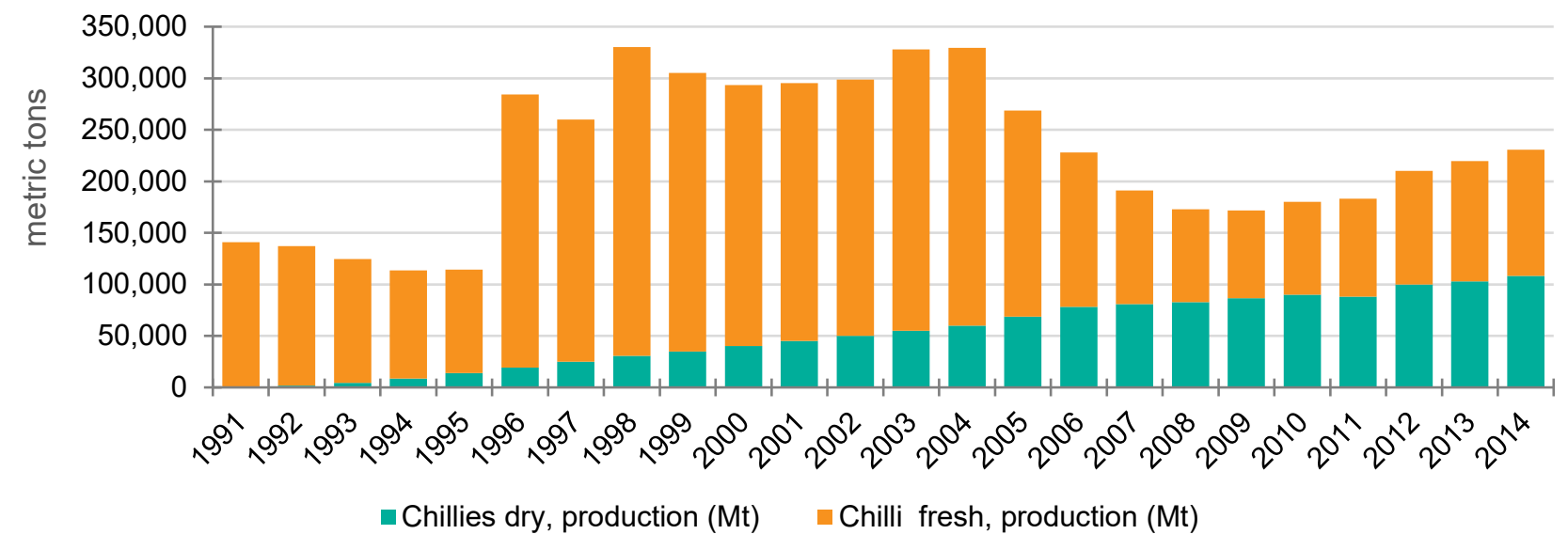

Source: FAOSTAT 2017

The acreage under fresh chili declined gradually from its peak at 76,800 ha in 1998 to about 14,400 ha in 2014 , while that of dry chili remains constant at 14,000 ha (Figure 2). In 2015, green chilies and peppers were planted on 14,000 ha (MoFA 2015).

Production has, however, kept up with domestic consumption requirements. Small quantities of selected types of chilies are imported seasonally - as a share of domestic consumption, chili imports are much smaller than that of other vegetables, like tomatoes and onions. Chilies come from Cote d'Ivoire during the growing season. Imports come from Burkina Faso and Togo to supplement local production during the off-season. Small quantities of Scotch bonnet, a type of chili, are also imported from Europe. Between 2013 and 2015, MOTI estimates that chili imports were valued at only USD 65,000 annually. BACl, another database, on the other hand, suggests that chili import values are almost double at USD 116,000 annually (Van Asselt, Masias and Kolavalli 2018). 
Figure 2: Chili in Ghana, area under cultivation, 1991 to 2014

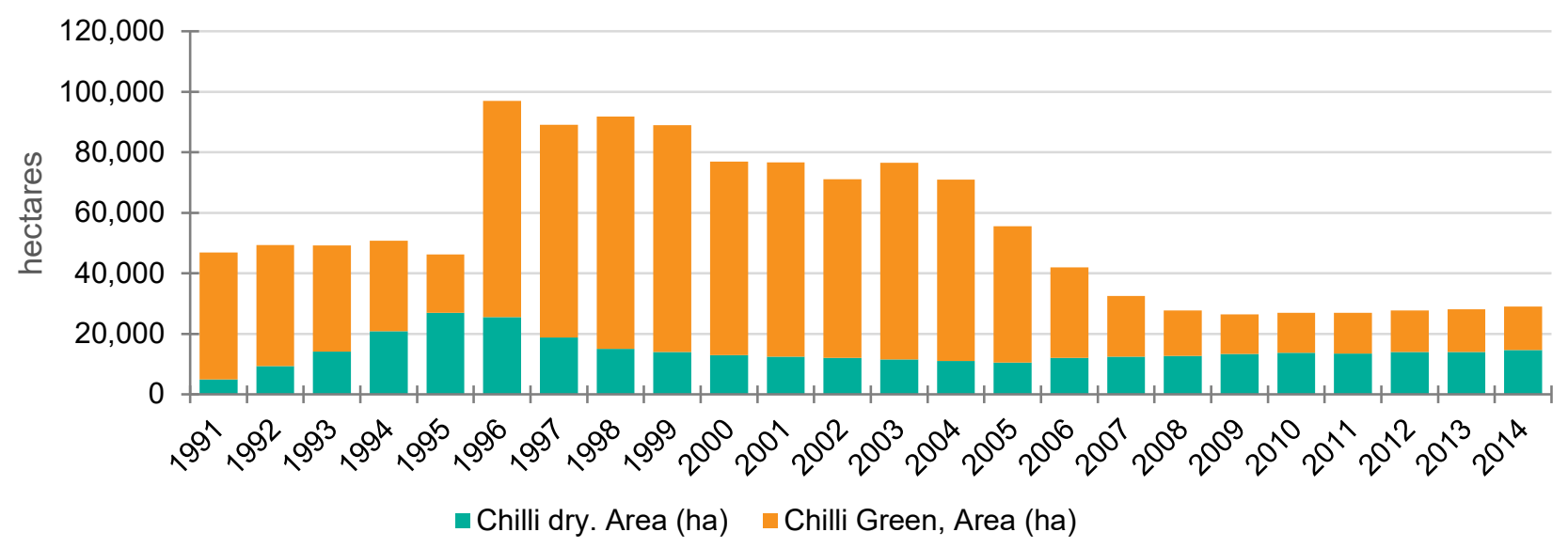

Source: FAOSTAT 2017.

Although exported in small quantities, green chili is the main vegetable exported from Ghana. Ghanaian chili exports have captured a considerable share of the UK market supplied from non-EU chili producing countries - however, the UK sources only 10 percent of its imports from non-EU countries. Between 2000 and 2007, Ghana increased its exports from 26,000 MT to 41,000 MT. Legon 18, a variety developed by the University of Ghana, is credited with growth in exports (MiDA 2011; DAI and Nathan Association Inc. 2014); bird's eye is the other chili variety exported.

Since 2007, chili exports have declined considerably following EU's ban on export of vegetables from Ghana for failing to meet the required phytosanitary conditions. Export revenues plummeted from USD 8.0 million in 2007 to USD 3.9 million in 2013. The ban, which was initially put in place until December 2016, was extended to December 2017. Ghana government subsequently banned exports by any producers not registered with Plant Protection and Regulatory Services Division of the Ministry of Food and Agriculture.

According to FAO, chili yields have grown since 1990. However, the most recent estimates are that yields are only around $8.00 \mathrm{MT} / \mathrm{ha}$, far below the achievable yield of $32.30 \mathrm{MT} / \mathrm{ha}$ (MoFA 2014). Other sources suggest much lower yields ranging from 3.5 to $7.8 \mathrm{MT} / \mathrm{ha}$ (Van Asselt, Masias, and Kolavalli 2018). The Legon 18 variety yields between 10 and 14 MT/ha (Nkansah, Ayarna, and Gbokie 2011). These productivity levels perhaps are more realistic of the yield potential for chili on farmers' fields.

The reasons for low yields are the limited potential of available varieties, poor quality seed, limited adoption of improved agronomic practices, including limited use of organic and inorganic fertilizers, and pest and disease damage. Producers are slow to adopt improved varieties because available improved varieties are commercialized only to a limited extent. High incidence of pests and diseases is also a key factor explaining observed low yields (Quartey et al. 2014; Bonsu et al cited in Nkansah, Ayarna and Gbokie 2011). Asare-Bediako et al. (2015) reported high incidence of viral and fungal diseases - phytophthora leaf blight, cercospora leaf spot, leaf anthracnose, fruit rot, and pepper mosaic - in the five districts they surveyed.

Many projects in recent years have sought to develop the chili sector. The Market Oriented Agriculture Program of the German Technical Cooperation implemented with the Ministry of Food and Agriculture helped producers and processors to increase chili production and to improve the quality of both primary and processed produce to meet market requirements. The project trained producers in Central, Volta and Brong-Ahafo regions, involved producers in the trials and selection of new varieties, such as MI 2 and Legon 18, and supplied some processors with improved drying technologies. After this project closed in 2013, another project, GhanaVeg, helped producers meet 
photo-sanitary standards to increase vegetable exports, including that of chili. The Export Marketing and Quality Awareness Project contributed to sector development by constructing pack houses and by training producers, exporters, traders, workers in pack houses, and other relevant decision makers.

Despite these interventions, numerous production and marketing constraints persist in Ghana's chili sector. Production is predominately rain-fed and constrained by poor husbandry techniques, pests and diseases, poor extension services, and a lack of organized post-harvest processing and marketing.

\section{Objectives of study}

This study aimed to identify opportunities for strengthening the competitiveness of the chili sector in Ghana. Two critical issues faced in inclusive value chain development are where to intervene in the value chain and how to intervene to build competitiveness - particularly in ways that are beneficial to smallholder-producers. We sought to gain insights on the first of these questions by answering the following:

- Where are the opportunities to increase productivity of chilies?

- Does the marketing system serve the farmers well in terms of delivering a significant share of the consumer prices, and are there opportunities to make the system more efficient?

This study follows the chili produced until the point in the value chain where the crop is sold to traders. Organizational and logistical limitations prevented examining the processing of chili into powders and other products. However, we do examine the limited value addition activities of producers who dry chilies before they sell to traders. Because this study was done as part of a study on value chain development, one of the intended objectives was also to examine the extent and nature of production under contract with buyers, whether traders or processors.

The analysis is made using original data collected from producers and traders in major chili producing zones of the Brong-Ahafo area, one of the leading production areas for chili in Ghana. ${ }^{1}$

The rest of the paper is organized into four sections. Section two presents the findings of a reconnaissance survey conducted in Brong-Ahafo prior to the survey. This survey identified traders and provided baseline information for the subsequent sampling of producers and traders. Section three presents the analysis of chili production practices based on survey data, including an estimation of production functions. Section four presents a discussion of how chilies are traded, an econometric modeling of price determination, and profitability. Section five summarizes and concludes.

\section{SCOPING SURVEY AND SAMPLING}

The Brong-Ahafo area was selected for the study because it is a major rainfed chili-producing zone in Ghana. Between January and March 2018, prior to undertaking the study, the research team conducted an exploratory survey in major chili markets in Brong-Ahafo and in selected markets in other chili producing areas and metropolitan areas. This was done to understand how chilies are sourced by traders and how prices, both wholesale and retail, varied across these markets.

In consultation with the regional MoFA office, the study team identified nine leading chili producing districts in Brong-Ahafo and the markets they served. Sunyani was the largest market,

\footnotetext{
${ }^{1}$ At the time this study was undertaken, Brong-Ahafo made up one of the ten regions of Ghana. However, in 2019 the region was divided into three new regions, namely Bono, Bono East, and Ahafo regions, and Brong-Ahafo ceased to exist as an administrative region.
} 
followed by Techiman, Kenyasi, and Wenchi, which are smaller, but all well connected to the Sunyani market. The other markets were Atebubu, Bechem, Dormaa Ahenkro, Drobo, and Seikwa, of which Seikwa was the most remote. Markets selected outside the region included Navrongo, Bolgatanga, and Yendi in the northern part of the country, Ho in the Volta region, and the Accra and Kumasi urban markets.

Enumerators visited the selected markets over three weeks to record prices of different types of chilies and to collect information from a sample of traders on where they sourced their supplies. Enumerators also traveled to other selected markets to understand whether Brong-Ahafo chilies reached them. The survey was conducted before the major season planting began in May and June 2018.

The information collected offered several insights on trading corridors and modality of marketing that described the nature of networks and the extent of integration of chili markets:

- Seasonal demand for fresh chilies is met with supplies from other parts of the country and from imports from neighboring countries. During the dry season, when the reconnaissance survey was conducted, the bulk of fresh chilies sold in the region's markets came from other regions. More than 80 percent of the fresh chilies - green long, red long, and red Scotch bonnets come from Northern and Upper East regions of Ghana and from Burkina Faso. The rest come from farmers in Brong-Ahafo who planted chili in the previous minor season. Dry chilies sold in the region, on the other hand, come from producers in Brong-Ahafo. Traders in the northern part of Ghana also source dry chilies directly from producers in Brong-Ahafo.

- The number of intermediaries between producers and consumers is low, and traders do not specialize in their functions. For example, only a small proportion of traders function exclusively as wholesalers, buying from producers to sell to other traders. In addition, wholesalers as a share of all traders were few in small markets. Most traders who purchase from producers also typically engage in retail sales, selling directly to consumers. In smaller markets, more than 80 percent of traders purchased chili directly from farmers.

- More than a third of the traders said they purchase chilies from producers at the farm gate. Dry chilies as opposed to fresh chilies were more likely to be purchased at the farm gate. Forty percent of traders that reported trading dry chili indicated that they purchased the product only at the farm gate, while 25 percent reported purchasing dry chili at both the farm gate and from farmers who brought chilies to market. Traders who traveled to distant markets generally reported purchasing directly from farmers rather than from wholesalers.

- Additionally, traders reported that they usually buy from farmers with whom they have a business relationship - more than a third of the traders interviewed reported doing so.

- A significant portion of those who purchase chili in distant markets do so collectively to reduce their transaction costs. Small groups of traders usually send one or two representatives to buy for the entire group. Eighty to ninety percent of traders in southern markets said that they were members of groups that purchased collectively. They bought from Bimbila, Navrongo, Paga, Togo, and Bawku - markets north of Brong-Ahafo - and from Volta region to the east. They also reported purchasing from farmers in Brong-Ahafo, although local wholesalers do not buy fresh chilies locally. Traders in the Kumasi market, however, did not report buying collectively to the extent that traders in Accra did - perhaps because they were closer to production centers.

- Traders transport their produce within Brong-Ahafo in taxis and in "motor kings", motorized three wheeled transporters. They transport chili across regions in buses and cars. 
- Retailers sell their chilies by quantity in units of half or full olonkas (tin cans used as a measure in markets across Ghana) or in black "rubbers" (plastic bags), while wholesaling usually is done using size 4 and size 5 woven sacks.

\section{Sample and questionnaires}

The study aimed to sample 900 producers, including a significant subsample that produce under contract, and 350 traders from markets in which Brong-Ahafo chilies are traded.

\section{Producers}

The study team began sampling by selecting the top chili producing districts in Brong-Ahafo. The 2010 Ghana census found that more than 1,000 growers produced chili in 11 of the 22 districts in Brong-Ahafo (GSS 2013). Producers were sampled from all these 11 districts (Table 1). The geographical dispersion of the districts and logistical limitations of the survey enabled sampling from at most 40 communities in the selected districts. The number of communities to be sampled in each selected district was allocated based on the relative distribution of chili growers (Table 1 , Column (4)).

The study listed communities with chili producers in the selected districts with the help of district offices of MoFA. The required number of communities for the selected districts were randomly selected from the lists. A complete listing of chili producing households - only those that produced to sell - in the selected communities was done in April 2018, which yielded a total of 1,860 chili producers. If a randomly selected community had less than 20 chili producing households, it was replaced by the next randomly selected community.

Table 1: Sampling of chili producers

\begin{tabular}{|c|c|c|c|c|}
\hline $\begin{array}{l}\text { (1) } \\
\text { Districts with more than } 1,000 \\
\text { chili growing households }\end{array}$ & $\begin{array}{l}\text { (2) } \\
\text { Chili growing } \\
\text { households }\end{array}$ & $\begin{array}{c}\text { (3) } \\
\begin{array}{c}\text { Percent of } \\
\text { total }\end{array}\end{array}$ & $\begin{array}{c}\text { (4) } \\
\text { Number of } \\
\text { communities } \\
\text { selected }\end{array}$ & $\begin{array}{c}\text { (5) } \\
\text { Number of chili } \\
\text { growing households in } \\
\text { selected communities }\end{array}$ \\
\hline Atebubu Amantin & 2,141 & 8 & 3 & 290 \\
\hline Berekum Municipal & 2,070 & 8 & 3 & 157 \\
\hline Dormaa Municipal & 2,916 & 11 & 4 & 123 \\
\hline Jaman North & 2,459 & 9 & 4 & 206 \\
\hline Jaman South & 4,215 & 16 & 7 & 198 \\
\hline Pru & 2,044 & 8 & 3 & 272 \\
\hline Sene East & 1,323 & 5 & 2 & 135 \\
\hline Sunyani West & 1,315 & 5 & 2 & 74 \\
\hline Tain & 4,574 & 17 & 7 & 171 \\
\hline Tano South & 1,714 & 7 & 2 & 73 \\
\hline Techiman Municipal & 1,496 & 6 & 2 & 161 \\
\hline Asutifi South & & & 3 & 80 \\
\hline Asutifi North & & & 3 & 87 \\
\hline Total & & & 45 & 2,027 \\
\hline
\end{tabular}

Source: Authors, with information from 2010 population census of Ghana (GSS 2013).

As this work was progressing, the study team learned that some producers in the region were operating under contract with two processors. Without being able to procure the cooperation of the processors to identify their contracted producers, the study included six communities in two additional districts, Asutifi South and Asutifi North, where, according to a government source, production was taking place under contract. With the addition of these two districts, the number of communities in our sample increased to 45 with a total of 2,027 producers. A total of 900 chili 
producing households were randomly selected from the 45 communities in proportion to their share in the population of chili producers listed.

\section{Traders}

We sought to interview 300 chili traders in markets in Brong-Ahafo and in the metropolitan areas of Kumasi and Accra. Traders were sampled only after the producer survey was completed to include only those who operated in markets in which the sampled producers sold their chili. Preliminary analysis of the producer survey suggested that 79 percent of the producers sold at the farm gate (farm gate sellers), and the remaining 21 percent took their produce to nearby markets (market sellers). Therefore, 79 percent of the traders in our sample were drawn from markets in which traders who buy from farm gate sellers are likely to operate. Since farm gate sellers did not take their produce to a market, the markets associated with their sales were identified by the answers producers who are farm gate sellers gave to two questions: "In which markets do they personally know one or more traders?" and "If they follow market prices, in which markets are they following prices?" We identified the most important chili markets as those mentioned most frequently by producers in answering the two questions.

This process resulted in the selection of twelve markets in Brong-Ahafo. ${ }^{2}$ All traders in these markets and those in Kumasi markets were listed regardless of the nature of their trading. A total of 490 traders were listed in September 2018. A sub-sample of 330 was randomly selected out of the listed traders, with 67 percent (221) from Brong-Ahafo markets, 20 percent (66) from Kumasi markets, and 13 percent (43) from Accra markets.

The study used structured questionnaires with both producers and traders, plus a simple community survey which collected information on units of measurement used, transport modes used, and marketing practices. The producer survey collected information on basic socioeconomic aspects, social network links among chili growers, including how they typically market their produce, production details on their last crop of chili, and the marketing of the last crop. Similarly, the trader survey collected information on how they usually trade and the specifics on their last complete transaction.

A team of enumerators implemented the producer survey from mid-June to mid-July 2018 . The trader survey was completed in the subsequent month.

\section{CHILI PRODUCTION}

\section{Production practices}

On average, the chili producers surveyed planted their last crop of chili on 7.8 acres, about a third of their total cultivated area - excluding their "no crops grown" area. The share planted to chili was 55 percent. Seventeen percent of the producers planted chili on rented land, paying 50 percent of production as rental fee.

Producers plant chili seven months a year because they benefit from two rainfall seasons. Planting dates differed between those who planted their last previous crop in 2016 and 2017. More than 80 percent of the producers who reported planting their last crop in 2016 did so between March and June, the major rainfall season. In contrast, those who reported last planting in 2017 did so from August to October, possibly because of delayed rains during the major season of 2017. A

\footnotetext{
${ }^{2}$ Hwidiem, Wenchi, Dormaa Ahenkro , Badu, Berekum, Techiman, Goaso, Atebubu, Yeji, Seikwa, Akruka, and Derma.
} 
small share of producers planted during other months as well, perhaps because they had access to irrigation -8 percent of producers reported irrigating their crops.

Producers leave their chili crops in their fields for as long as 24 months. Nearly half of producers of both types of chilies kept the crop in their fields for 6 to 8 months. A third of the long chili producers and one half of the round chili producers kept their crop on the ground for longer than 8 months. However, while long chili producers harvested more by keeping the crop in the field longer, round chili producers did not (Table 2).

Table 2: Chili crop duration and yields obtained

$\begin{array}{lcccccc}\begin{array}{c}\text { Number of months } \\ \text { chili crop in field }\end{array} & \begin{array}{c}\text { Number of } \\ \text { producers }\end{array} & \begin{array}{c}\text { Long chilies } \\ \text { Harvest }\end{array} & \begin{array}{c}\text { Yield } \\ \text { (total bags) }\end{array} & \begin{array}{c}\text { Number of } \\ \text { (bags/acre) }\end{array} & \begin{array}{c}\text { Harvest } \\ \text { producers }\end{array} & \begin{array}{c}\text { Yield } \\ \text { (total bags) }\end{array} \\ \text { (bags/acre) }\end{array}$

Source: Brong-Ahafo Chili Producer Survey; 2018-19

Although most producers cultivated improved varieties, they do not buy certified seeds. Over 85 percent of long chili growers and about 70 percent of round chili growers recycled their seeds (Table 3). Only 2 to 3 percent purchased seed from an agricultural input company. Those who purchased from the market are likely to have purchased recycled seeds from traders.

Table 3: Source of chili seed

\begin{tabular}{lcccc} 
& \multicolumn{2}{c}{ Long chilies } & \multicolumn{2}{c}{ Round chilies } \\
& Frequency & Percent & Frequency & Percent \\
Own seed & 595 & 86.7 & 153 & 70.8 \\
Purchased seed from company & 23 & 3.3 & 4 & 1.8 \\
Government-supplied seed & 1 & 0.1 & 0 & 0.0 \\
Contract farming arrangement & 7 & 1.0 & 0 & 0.0 \\
Market & 34 & 5.0 & 32 & 14.8 \\
Another farmer & 22 & 3.2 & 25 & 11.6 \\
Other & 4 & 0.6 & 2 & 0.9 \\
\hline Total & 686 & 100.0 & 216 & 100.0 \\
\hline
\end{tabular}

Source: Brong-Ahafo Chili Producer Survey; 2018-19

Table 4: Labor use in long chili production

\begin{tabular}{lrcrc}
\multicolumn{1}{c}{ Activity } & \multicolumn{2}{c}{ Non-family labor (person days) } & $\begin{array}{c}\text { Family labor, } \\
\text { persons* }\end{array}$ \\
Land preparation & 4.42 & 0.52 & 4.94 & 1.61 \\
Planting & 2.44 & 0.11 & 2.55 & 2.43 \\
Fertilizer application & 0.56 & 0.03 & 0.59 & n.a. \\
Weeding & 13.81 & 0.54 & 13.85 & 1.54 \\
Harvest (average) & 1.42 & 0.21 & 1.65 & 2.21 \\
\hline Total & 22.65 & 1.41 & 23.58 & 5.36 \\
\hline
\end{tabular}

Source: Brong-Ahafo Chili Producer Survey; 2018-19

Note: * Number of family members working on the operation. n.a. = "not applicable".

Labor is an important input for chili production. In addition to using family labor, producers hired labor and participated in labor exchanges. Almost 60 percent of the hired and exchange labor used by child producers went into weeding (Table 4). Although chili harvesting is labor-intensive, households relied on non-family labor for only 7 percent of the labor used for harvesting - possibly 
because it is an activity that can be spread out over several weeks so can be done by family members. On average, close to three family members engaged in hired-out or exchange labor.

A third of long chili producers and more than one half of round chili producers planted on ridges - perhaps to reduce runoff. They usually plant 2 feet apart both between and within rows. This spacing is close to what is recommended by MoFA. Most producers plant chili as a monocrop.

Producers fertilize their chili only at low levels (Table 5). Long chili producers applied 0.66 bags (33 kg) of NPK and 0.32 bags (16 kg) of ammonium sulfate per acre. Round chili producers applied somewhat more -2.14 bags $(107 \mathrm{~kg})$ of NPK and 0.71 bags $(35 \mathrm{~kg})$ of ammonium sulfate.

Although there is no official fertilizer recommendation for chilies from MoFA, the guidelines from scientists evaluating chili yield response to fertilizer reported good results from applying 112 $\mathrm{kg} / \mathrm{acre}$ of NPK and $50 \mathrm{~kg} / \mathrm{acre}$ of ammonium sulfate (Nkansas, Ayarna and Gbokie 2011). Round chili producers in our sample came close to applying fertilizer at such levels.

Table 5: Fertilizer application by chili producers

\begin{tabular}{lccccccc} 
& \multicolumn{3}{c}{ Long chilies } & \multicolumn{3}{c}{ Round chilies } \\
\multicolumn{1}{c}{ Fertilizer } & $\begin{array}{c}\text { Observa- } \\
\text { tions }\end{array}$ & Mean & $\begin{array}{c}\text { Standard } \\
\text { deviation }\end{array}$ & $\begin{array}{c}\text { Observa- } \\
\text { tions }\end{array}$ & Mean & $\begin{array}{c}\text { Standard } \\
\text { deviation }\end{array}$ \\
\hline NPK, bags applied & 652 & 0.66 & 1.26 & 224 & 2.14 & 2.86 \\
Ammonium sulfate, bags applied & 652 & 0.32 & 0.67 & 224 & 0.71 & 1.32 \\
Urea, bags applied & 652 & 0.03 & 0.20 & 224 & 0.07 & 0.36 \\
Fertilizer applications, number & 652 & 1.35 & 1.25 & 224 & 2.39 & 2.19 \\
Fertilizer used/application, olonka & 652 & 4.29 & 5.69 & 224 & 9.29 & 9.51 \\
\hline
\end{tabular}

Source: Brong-Ahafo Chili Producer Survey; 2018-19.

Chili growers weeded the fields either three or four times over a period of twelve months. Long chili producers sprayed their crop either three or four times, while round chili producers sprayed up to six times. Vegetable producers often apply plant protection chemicals indiscriminately, mixing different chemicals. Most chili producers appear to have applied only one chemical to their crop.

While only 8 percent of long chili producers used irrigation, more than a third of the round chili producers did. They also did for longer periods - for close to 8 weeks compared to 4.5 weeks by long chili producers.

More than half of long chili producers and more than a third of round chili producers reported crop-damaging shocks (Table 6). Among those who reported such shocks, long chili producers reported that they lost a third of the crop that they otherwise would have harvested; round chili producers estimated losing about a fifth of their crop. Diseases and pests were the dominant shocks reported by both. Although nearly all produce chilies without irrigation, dry spells were named as a reason for crop loss by less than five percent of producers.

Table 6: Crop damage from shocks

\begin{tabular}{|c|c|c|c|c|c|c|c|c|c|c|}
\hline & \multicolumn{5}{|c|}{ Long chilies } & \multicolumn{5}{|c|}{ Round chilies } \\
\hline & $\begin{array}{l}\text { Obser- } \\
\text { vations }\end{array}$ & Mean & $\begin{array}{l}\text { Stnd. } \\
\text { dvtn. }\end{array}$ & $\begin{array}{l}\text { Mini- } \\
\text { mum }\end{array}$ & $\begin{array}{l}\text { Maxi- } \\
\text { mum }\end{array}$ & $\begin{array}{l}\text { Obser- } \\
\text { vations }\end{array}$ & Mean & $\begin{array}{l}\text { Stnd. } \\
\text { dvtn. }\end{array}$ & $\begin{array}{l}\text { Mini- } \\
\text { mum }\end{array}$ & $\begin{array}{l}\text { Maxi- } \\
\text { mum }\end{array}$ \\
\hline $\begin{array}{l}\text { Crop damaged from } \\
\text { shocks, share 'Yes' }\end{array}$ & 652 & 0.56 & 0.50 & 0 & 1 & 224 & 0.35 & .0 .48 & 0 & 1 \\
\hline $\begin{array}{l}\text { Average estimated crop } \\
\text { loss, percent of expected } \\
\text { harvest }\end{array}$ & 364 & 29.5 & 23.5 & 0 & 98 & 96 & 20.7 & 21.3 & 0 & 98 \\
\hline $\begin{array}{l}\text { Expected harvest without } \\
\text { shocks, bags }\end{array}$ & 351 & 8.9 & 11.4 & 0 & 10 & 88 & 14.3 & 23.2 & 1 & 130 \\
\hline
\end{tabular}

Source: Brong-Ahafo Chili Producer Survey; 2018-19 


\section{Econometric model of long chili production in Ghana}

We estimate a Cobb-Douglas type of production function to quantify the marginal contributions of various inputs to long chili (dry) yields. The Cobb-Douglas estimation assumes constant returns to scale, so in this case adding up the estimated coefficients for land, labor, and fertilizer gives a number less than one, which implies decreasing returns to scale. The model specification is:

$$
\ln Y_{i}=\alpha_{1}+\beta_{1} x_{1}+\sum_{i=1}^{N} \beta_{i} x_{i}+\sum_{i=1}^{N} \delta_{i} z_{i}+\sum_{i=1}^{N} \pi_{i} D_{i}+\pi_{2} x_{2}+\varepsilon_{i}
$$

Where: $Y_{i}$ is the log transformation of the quantity of dry chili harvested; $\alpha_{1}$ is a constant; $x_{i}$ are producer characteristics, including age, gender, if always lived in the community, education level, and years of experience in chili cultivation; $z_{i}$ are inputs into chili cultivation, including land size, kilos of fertilizer applied, and person-days of hired labour used; $D_{i}$ are binary indicators measuring farming practices relating to how fertilizer, plant protection and irrigation are applied and categorical variables to control for the season in which the chili was planted; $\varepsilon_{i}$ is a composite error term. The Cobb-Douglas specification is in logarithms to enable a straightforward interpretation of the coefficients as elasticities of production relative to marginal unit changes in the explanatory variables used.

The production function is estimated using the sample of farmers who produced long chilies. Descriptive statistics on the variables used in the estimation are presented in Table 7.

Table 7: Descriptive statistics for variables in long chili production function estimation

\begin{tabular}{|c|c|c|c|c|}
\hline Variable & Mean & $\begin{array}{l}\text { Standard } \\
\text { deviation }\end{array}$ & Minimum & Maximum \\
\hline Long chili harvested, $\mathrm{kg}$ & 478.3 & 393.1 & 16 & 3,556 \\
\hline Age, years & 42.4 & 11.6 & 16 & 88 \\
\hline Male growers, $0 / 1$ & 0.31 & 0.46 & 0 & 1 \\
\hline Grower born locally, $0 / 1$ & 0.81 & 0.39 & 0 & 1 \\
\hline Highest schooling category completed by producer * & 2.02 & 1.16 & 1 & 7 \\
\hline Experience cultivating chili, years & 8.4 & 7.5 & 0 & 55 \\
\hline \multicolumn{5}{|l|}{ When was long chili planted } \\
\hline Dry season (Jan. to March), $0 / 1$ & 0.13 & 0.34 & 0 & 1 \\
\hline Major season (April to July), 0/1 & 0.71 & 0.46 & 0 & 1 \\
\hline Minor season (August to Nov.), 0/1 & 0.16 & 0.37 & 0 & 1 \\
\hline \multicolumn{5}{|l|}{ Production technology } \\
\hline Land planted to chili, acres & 1.59 & 1.15 & 0.5 & 12.5 \\
\hline Legon 18 variety, $0 / 1$ & 0.70 & 0.46 & 0 & 1 \\
\hline Red cayenne variety, $0 / 1$ & 0.27 & 0.44 & 0 & 1 \\
\hline Other variety, $0 / 1$ & 0.04 & 0.19 & 0 & 1 \\
\hline Plant chilies on ridges, $0 / 1$ & 0.30 & 0.46 & 0 & 1 \\
\hline Fertilizer applied by broadcasting, 0/1 & 0.05 & 0.21 & 0 & 1 \\
\hline Applications of fertilizer, number & 1.35 & 1.25 & 0 & 8 \\
\hline Total fertilizer used, bags & 0.84 & 1.47 & 0 & 21.37 \\
\hline Pesticide applications, number & 3.66 & 6.49 & 0 & 131 \\
\hline Irrigation, 0/1 & 0.08 & 0.26 & 0 & 1 \\
\hline \multicolumn{5}{|l|}{ Hired labour used } \\
\hline Hired person-days (paid \& exchange), total & 37.0 & 332.5 & 0 & 8,432 \\
\hline Paid person-days, total & 35.4 & 332.5 & 0 & 8,432 \\
\hline Household members working on chili, number & 6.49 & 6.31 & 0 & 38 \\
\hline
\end{tabular}

Source: Brong-Ahafo Chili Producer Survey; 2018-19. Observations: 651 long chili producers.

Note: * Educational attainment categories: $1=$ no schooling, $2=$ primary, $3=$ junior secondary, $4=$ senior secondary or above.

The sample is made up of 651 producers, 31 percent of whom are male and, on average, are 42 years old. The average schooling completed in the sample is primary level, though half of the 
sample has not completed a year of schooling and 30 percent has completed middle junior high. Eighty-one percent of the producers are indigenous to the community surveyed. The producers have a mean of eight years' experience in chili production.

Seventy one percent of the sample planted long chilies in the major season (i.e. between April and July). The average harvest for the sample producers was 478 kilograms from an average 1.59 acres. This area corresponds to one-third of the total acreage cultivated by these producers under any crop during the season in which the survey was conducted. Seventy percent planted the Legon 18 long chili variety, while 27 percent planted red cayenne. The bulk of the long chili harvested was sold dry (98 percent). For this reason, our later analysis of the determinants of chili prices will focus on dry chilies.

After converting all fertilizer application levels into a common unit measure, the data indicates that producers on average use less than one bag of fertilizer. Five percent of the sample applies fertilizer by broadcasting, either alone or in combination with some other method and makes an average of 1.35 applications of fertilizer throughout the crop year. Chili plants are sprayed against pests and diseases on average nearly 4 times per year. Less than one-third of the sample plants long chilies on ridges. Eight percent of sampled producers irrigated their fields. Labor data suggest that on average growers use 37 person-days of hired labor, most of which is paid labor.

The estimates of the production function specified in equation (1) are presented in Table 8. They show the results from the log transformation of the dependent variable (dried chili production in $\mathrm{kg}$ ) against a number of explanatory covariates in levels, percentages, and also logarithmically transformed.

Table 8: Production function estimates for long chili (dry) producers

\begin{tabular}{lcccc} 
Dependent variable: In (kg long chili harvested (dry)) & Coefficient & $\begin{array}{c}\text { Standard } \\
\text { Error }\end{array}$ & t & p-value \\
Age, years & 0.00 & 0.00 & -0.93 & 0.36 \\
Male growers, 0/1 & 0.22 & 0.07 & 2.93 & 0.01 \\
Grower born locally, 0/1 & -0.20 & 0.06 & -3.44 & 0.00 \\
Highest schooling completed by producer * & -0.02 & 0.02 & -0.93 & 0.36 \\
Experience cultivating chili, years & -0.01 & 0.00 & -1.77 & 0.09 \\
In (land planted to chili, acres) & 0.39 & 0.09 & 4.28 & 0.00 \\
Fertilizer applied by broadcasting, 0/1 & 0.44 & 0.08 & 5.28 & 0.00 \\
Applications of fertilizer, number & -0.02 & 0.03 & -0.68 & 0.50 \\
In (total fertilizer used, bags)** & 0.32 & 0.05 & 6.39 & 0.00 \\
In (hired person-days (paid \& exchange)) & 0.01 & 0.04 & 0.13 & 0.90 \\
Household members working on chili, number & -0.07 & 0.12 & -0.54 & 0.59 \\
Planted in the major season (April to July), 0/1*** & 0.21 & 0.11 & 1.89 & 0.07 \\
Planted in the minor season (August to Nov.), 0/1*** & 0.02 & 0.11 & 0.20 & 0.84 \\
Grew Legon 18 variety, 0/1*** & 0.06 & 0.08 & 0.82 & 0.42 \\
Grew red cayenne variety, 0/1*** & -0.04 & 0.10 & -0.40 & 0.69 \\
Planted chilies on ridges, 0/1 & -0.07 & 0.07 & -1.15 & 0.26 \\
Used irrigation, 0/1 & -0.05 & 0.08 & -0.60 & 0.55 \\
Constant & 6.21 & 0.22 & 28.17 & 0.00 \\
\hline Observations & 651 & &
\end{tabular}

*Educational attainment categories used: 1 = no schooling, 2= primary, 3=junior secondary, 4= senior secondary or above.

** Variable was augmented by one before its log transformation to avoid missing observations for respondents not applying fertilizer. A dummy variable for all growers who did not use any fertilizer was added to the regression to correct for the bias introduced by this change. The results for this dummy variable are not reported in the table.

*** Dry season is the reference category.

**** 'Do not know long chili variety grown' is the reference category. 
Male growers produce significantly more chilies: a 1 percent increase in the share of men producers is associated with 20 percent higher production of long chilies. Conversely, natives produce less than do migrants into their communities: a 1 percent increase in the percentage of growers who were born in the community is associated with 20 percent lower production. Schooling and years of chili cultivation experience were found to have no statistically significant association with production.

Land area planted to chili and fertilizer use are directly and strongly associated with chili production. A 10 percent increase in land under chili cultivation is associated with a 4 percent increase in long chili harvested. A 10 percent increase in the number of fertilizer bags used correlates with a 3.2 percent increase in chili harvested. The method of and the number of fertilizer applications, however, yield counterintuitive results. Broadcasting of fertilizers, which is an inefficient method practiced by 5 percent of the sample, is associated with a 44 percent increase in production. In contrast, the number of applications of fertilizer is not significantly associated with yield, although the application of a given quantity of fertilizer in several doses should result in better utilization of fertilizers compared to the application of the same quantity in fewer doses.

Finally, those that planted in the major season (April to July) produced more: increasing by one percentage point the share of growers planting in the major season is associated with up to 21 percent higher production levels. No other production input, including labor, seems to matter significantly for output levels.

In general, all the directions of association between inputs and farming practices, on the one hand, and quantity harvested, on the other, are as one might expect. Applying more fertilizer is positively associated with higher production of chilies. However, the degree of correlation between production and some inputs is not as strong as expected. For example, ridging and irrigation do not significantly affect output levels. However, we also find that few respondents adopt these techniques.

\section{CHILI MARKETING}

\section{Producer perspectives}

Producers market their chilies independently. Less than two percent reported that they were members of a farmer-based organization, a susu (traditional savings) group, or a chili producing group. Just over a quarter said that they were not part of any group. Most do engage in labor exchanges - only 12 percent of them reported being members of a labor exchange group. Twothirds of the chili producers, however, were members of religious groups. They generally are active in their communities - nearly two-thirds stated that they "regularly" or "once in a while" interact with their assembly representative.

When asked about how they market their chilies, most producers stated that they are not familiar with the traders that come to their communities, possibly because the same traders may not be visiting the community repeatedly. Only 129 producers (13 percent of the sample) could name a trader that comes into their community. Less than half of producers reported having the mobile telephone number of a trader, and only 12 percent reported having received a call from a trader or having called a trader to discuss chili sales. Traders, on the other hand, suggest that they usually buy from producers with whom they are familiar.

Despite not acknowledging familiarity with traders that come to their communities, the producers generally indicated that they had engaged in arrangements that might suggest some familiarity with a trader. Nearly 400 (41 percent) producers said that they had given chilies on credit to traders in 
the past. Of these producers, 269 (67 percent) said they would be willing to provide chilies on credit to traders again. However, a much smaller percent reported having taken any advances from a trader. Producing chilies under contract with a trader or a processor is rare -57 (6 percent) of producers reported having done so. But of these, two-thirds stated that they were satisfied with the outcome of this contracting arrangement, and that they would be willing to produce chilies under contract again.

Responding to general questions on how trading takes place in their communities, the sampled producers noted that they make the bulk of their sales in their communities, as suggested by the reconnaissance survey. However, the transactions take place between individuals - producers and traders - without the involvement of any formal or informal community organization. Only 23 producers ( 2 percent) noted that chili producers in their communities negotiate prices collectively with traders.

Generally, two or more traders visit the communities to buy both fresh and dry chilies. Producers in only two of the 45 surveyed communities reported not having any trader purchase chili in their communities (Appendix Table A1). However, producers within same communities reported significantly different numbers of traders coming to the community. In several surveyed communities, at least one producer noted that no trader came to the community, while others reported as many as 100 came. The producers reported that the traders who operated in their communities were either community members or from markets within the region.

With regards to producers' knowledge of prices in nearby markets, 57 percent said that they were not aware of the prevailing chili prices in any market close to them. This may reflect them having been interviewed out of season, and chili prices varying widely from day to day. Of the 122 who said they knew the price in a nearby market, 36 percent said they came to know the price from a trader. Other sources of price information were other farmers and the market itself -- perhaps from a visit there.

\section{Trader perspectives}

The average age of the traders interviewed was 42 years, 90 percent were women; and they had been trading for an average of 14 years and a median of 10 years. Nearly three-quarters of them had a permanent stall in the market in which they operate, and those who do, have had them for an average of 13 years. One-half of them store chilies overnight in their stalls.

Table 9: Sources of chilies for traders, share of traders using source

\begin{tabular}{lc}
\multicolumn{1}{c}{ Source of chilies } & Traders, percent \\
Producers at farm gate & 34.7 \\
Producers who deliver to market & 44.6 \\
Agents who deliver to market & 12.3 \\
Obtain Ghana chilies from wholesalers & 46.7 \\
Obtain imported chilies from wholesalers & 1.5 \\
\hline
\end{tabular}

Source: Brong-Ahafo Chili Producer Survey; 2018-19

Note: Sum of percentages exceeds 100 because traders generally buy from several sources.

Chili traders buy from several sources (Table 9). At least three-quarters buy directly from farmers, whether at the farm gate or in a market. Nearly one-half buy from wholesalers. However, this information on sources of chili does not give any indication of the proportion of the total produce traded that comes from the various sources.

Eighty-five percent of traders reported that they make retail sales directly to consumers: 19 percent to wholesalers, 51 percent to retailers, and 4 percent to agents. Only a small portion of them are specialized in their trading, whether trading only as wholesalers or as retailers. With 
nearly three-quarters of traders buying at least a portion of their chilies from producers and 85 percent of them retailing those chilies, this suggests that trading with only one intermediary between chili producers and consumers is quite a common pattern. The chili value chain is short, particularly for local trading.

As the reconnaissance survey suggested, traders buy directly from producers in distant production areas rather than buying from agents or traders. In doing so, traders act collectively to a limited degree - 17 percent of them belong to trader groups. A third of these traders said that their group sets farm gate prices and quotas on how much they can bring to the markets within their purview.

Half of the traders interviewed reported trading only fresh round chilies. About 40 percent buy and sell dry long chilies. A small percent of them trade in chili powder.

\section{Price determination}

We estimate the determinants of prices for dry long chilies and for fresh round chilies.

Understanding how trading prices are determined in the value chain is central to establishing the level of efficiency in the chain and to identifying the nodes along the chain where improvements in trading terms are possible to better integrate producers in value-addition activities within the system.

Producers in the chili value chain in the Brong-Ahafo area face a variety of transaction costs that are commonly seen in other value chains in developing countries (Pingali et al. 2019). These include low economies of scale, low bargaining power, poor connectivity to markets, and asymmetric information in pricing between producers and traders resulting from poor knowledge of product quality and spatial variation in market opportunities. Some of these obstacles play against the ability of producers to receive competitive prices. These challenges are analyzed separately for fresh round chili and for dry long chili to account for marketing differences due, for example, to the degree of perishability of the crop and variable connectivity to distant markets offering different prices. This log-linear equation represents the basis of our empirical estimates:

$$
\ln P_{i}=\alpha_{1}+\beta_{1} x_{1}+\beta_{2} x_{2}++\delta x_{3}+\beta_{3} x_{3}+\varepsilon_{i}
$$

$\ln P_{i}$ is the log transformed price of chili ( $i=$ fresh round or dry long). $x_{1}$ are characteristics of growers, including age, gender, whether completed primary school, or if local in origin. $x_{2}$ are marketing choice variables, including a dummy for sales at the market, the total number of fresh harvests obtained in the twelve months preceding the survey, the number of months between planting and the end of harvest, and the physical distance from the community of the respondent to the nearest market. Vector $x_{3}$ includes variables that proxy for social networks of respondents. These include whether the producer knows personally the trader and whether the producer knows the price at which fellow producers sell their chili. For the fresh round chili model, we also include the number of traders known in the community, and the number of local farmers' organizations. Finally, for long chili growers, $x_{3}$ also includes a number of additional variables, including the share of growers who know the market price of dry long chilies, the number of weeks the crop was stored prior to sale, and knowledge of the variety grown. Finally, $\varepsilon i$ is the composite error. Descriptive statistics for the variables used in the price determination models are presented in Table 10. 
Table 10: Descriptive statistics of variables used in the chili price determinants models

\begin{tabular}{|c|c|c|c|c|}
\hline \multirow[b]{2}{*}{ Variable name } & \multicolumn{2}{|c|}{ Dry long chili } & \multicolumn{2}{|c|}{ Fresh round chili } \\
\hline & Mean & $\begin{array}{l}\text { Standard } \\
\text { deviation }\end{array}$ & Mean & $\begin{array}{l}\text { Standard } \\
\text { deviation }\end{array}$ \\
\hline Chili price, GHф/bag - dependent variable & 279.40 & 128.70 & 195.40 & 94.79 \\
\hline \multicolumn{5}{|l|}{ Producer characteristics } \\
\hline Age, years & 42.3 & 11.80 & 42.2 & 9.93 \\
\hline Male, $0 / 1$ & 0.30 & 0.46 & 0.65 & 0.48 \\
\hline Born in district, $0 / 1$ & 0.81 & 0.39 & 0.84 & 0.36 \\
\hline Received any education, $0 / 1$ & 0.30 & 0.46 & 0.46 & 0.50 \\
\hline \multicolumn{5}{|l|}{ Marketing choices } \\
\hline Sold chilies at the market, $0 / 1$ & 0.18 & 0.38 & 0.36 & 0.48 \\
\hline Chili harvests in past year, number & 8.9 & 3.64 & 8.5 & 3.31 \\
\hline Period from planting to end of harvest, months & 9.0 & 4.44 & 8.1 & 2.92 \\
\hline Distance to nearest market, $\mathrm{km}$ & 13.5 & 23.25 & 8.3 & 3.91 \\
\hline \multicolumn{5}{|l|}{ Marketing arrangements } \\
\hline Knows trader personally, $0 / 1$ & 0.54 & 0.50 & 0.68 & 0.47 \\
\hline Aware of prices at which other farmers sell, $0 / 1$ & 0.70 & 0.46 & 0.77 & 0.42 \\
\hline Traders buying in community in last year, no. & & & 7.82 & 9.67 \\
\hline Farmers organizations in community, number & & & 0.20 & 0.63 \\
\hline \multicolumn{5}{|l|}{ Dry long chili features } \\
\hline Knows price of chili in any market, $0 / 1$ & 0.36 & 0.48 & & \\
\hline Period over which chilies stored, weeks & 7.1 & 5.17 & & \\
\hline Variety grown is Legon $18,0 / 1$ & 0.30 & 0.46 & & \\
\hline Variety grown is red cayenne, $0 / 1$ & 0.27 & 0.44 & & \\
\hline Does not know variety grown, $0 / 1$ & 0.43 & 0.50 & & \\
\hline Observations & \multicolumn{2}{|c|}{639} & \multicolumn{2}{|c|}{223} \\
\hline
\end{tabular}

Source: Authors' calculations from Brong-Ahafo Chili Producer Survey; 2018-19.

The average price of fresh round chili is 30 percent lower than that of dry long chilies, which is likely to be attributed - among other things - to the longer shelf life of dry chilies. Producers are on average aged in their early 40 s. Fresh round chili producers are predominantly men, while women prevail in production of dry long chili . Less than half of the producers in the sample have received any schooling.

Most sales take place at the farm gate for both products. Farmers on average harvest just under nine times per year, with each chili crop being in the field between eight and nine months. The average distance to the nearest market is between 8 (fresh round chilies) and 14 (dry long chilies) kilometers.

More than half of the producers personally know the traders who come and buy chili in their community, and three-quarters report knowing the price at which other growers sell their chilies. Fresh round chili growers report that on average about 8 traders come each season to buy chili in their community, and that farmers organizations are not common. A third of dry long chili growers know the price of the crop in the market. On average, the store their dry long chili crop for seven weeks prior to selling. Finally, when asked about the variety of long chili grown, 30 percent reported Legon 18, 27 percent reported red cayenne, and the remaining said they either did not know what variety they grew or reported another variety altogether.

Table 11 reports the results of estimating the ordinary least squares (OLS) model of the chili price determination model in equation (2) for the two types of chili. As noted, while most covariates are the same in the two models, we employ different sets of explanatory variables for marketing arrangements and produce features, as these will have a different influence on the bargaining power producers have in price determination. 
Table 11: Ordinary Least Squares (OLS) estimates of price determinants model

\begin{tabular}{|c|c|c|c|c|c|c|c|c|}
\hline \multirow[t]{2}{*}{ Dependent variable: } & \multicolumn{4}{|c|}{ In(dry long chili price, GHф/bag) } & \multicolumn{4}{|c|}{ In(fresh round chili price, GHф/bag) } \\
\hline & $\begin{array}{l}\text { Coeffic- } \\
\text { ient }\end{array}$ & $\begin{array}{l}\text { Standard } \\
\text { error }\end{array}$ & $\mathbf{t}$ & $p$-value & $\begin{array}{l}\text { Coeffic- } \\
\text { ient }\end{array}$ & $\begin{array}{l}\text { Standard } \\
\text { error }\end{array}$ & $\mathbf{t}$ & p-value \\
\hline \multicolumn{9}{|l|}{ Producers' characteristics } \\
\hline Age, years & 0.00 & 0.00 & 0.82 & 0.42 & 0.00 & 0.01 & 0.03 & 0.98 \\
\hline Male, 0/1 & 0.01 & 0.08 & 0.14 & 0.89 & 0.03 & 0.09 & 0.31 & 0.76 \\
\hline Born in district, $0 / 1$ & 0.09 & 0.12 & 0.75 & 0.46 & 0.19 & 0.06 & 3.08 & 0.01 \\
\hline Received any education, $0 / 1$ & 0.16 & 0.05 & 3.55 & 0.00 & -0.01 & 0.06 & -0.23 & 0.82 \\
\hline \multicolumn{9}{|l|}{ Marketing choices } \\
\hline Sold chilies at the market, $0 / 1$ & -0.22 & 0.06 & -3.83 & 0.00 & 0.30 & 0.15 & 2.03 & 0.05 \\
\hline Chili harvests in past year, no. & 0.02 & 0.01 & 3.08 & 0.00 & 0.00 & 0.01 & 0.54 & 0.59 \\
\hline $\begin{array}{l}\text { Period from planting to end of } \\
\text { harvest, months }\end{array}$ & 0.07 & 0.02 & 3.76 & 0.00 & 0.17 & 0.10 & 1.83 & 0.08 \\
\hline $\begin{array}{l}\text { Square of period from planting to } \\
\text { end of harvest, months }\end{array}$ & -0.003 & 0.001 & -3.90 & 0.00 & -0.01 & 0.00 & -1.68 & 0.10 \\
\hline Distance to nearest market, $\mathrm{km}$ & 0.00 & 0.00 & -1.22 & 0.23 & 0.02 & 0.02 & 1.07 & 0.30 \\
\hline \multicolumn{9}{|l|}{ Marketing arrangements } \\
\hline Knows trader personally, $0 / 1$ & 0.10 & 0.06 & 1.68 & 0.10 & 0.30 & 0.15 & 1.97 & 0.06 \\
\hline $\begin{array}{l}\text { Aware of prices at which other } \\
\text { farmers sell, } 0 / 1\end{array}$ & 0.12 & 0.05 & 2.42 & 0.02 & -0.24 & 0.11 & -2.09 & 0.05 \\
\hline $\begin{array}{l}\text { Traders buying in community in } \\
\text { last year, number }\end{array}$ & & & & & -0.02 & 0.00 & -6.12 & 0.00 \\
\hline $\begin{array}{l}\text { Farmers organizations in } \\
\text { community, number }\end{array}$ & & & & & -0.13 & 0.15 & -0.91 & 0.37 \\
\hline \multicolumn{9}{|l|}{ Dry long chili features } \\
\hline $\begin{array}{l}\text { Knows price of chili in any } \\
\text { market, } 0 / 1\end{array}$ & -0.07 & 0.06 & -1.21 & 0.24 & & & & \\
\hline $\begin{array}{l}\text { Period over which chilies stored, } \\
\text { weeks }\end{array}$ & -0.16 & 0.07 & -2.23 & 0.03 & & & & \\
\hline Variety grown red cayenne, $0 / 1$ & 0.00 & 0.00 & -0.48 & 0.64 & & & & \\
\hline Does not know variety grown, $0 / 1$ & 0.06 & 0.07 & 0.76 & 0.45 & & & & \\
\hline Constant & 4.79 & 0.22 & 21.56 & 0.00 & 3.95 & 0.58 & 6.78 & 0.00 \\
\hline \multirow[t]{2}{*}{ Observations } & & 639 & & & & 223 & & \\
\hline & \multicolumn{4}{|c|}{$\begin{array}{l}F(17,38): 24.36 ; \text { Prob > F: } 0.000 ; \\
\text { R-squared: } 0.15\end{array}$} & \multicolumn{4}{|c|}{$\begin{array}{l}\mathrm{F}(17,38): 7.84 ; \text { Prob > F: } 0.000 \\
\text { R-squared: } 0.25\end{array}$} \\
\hline
\end{tabular}

Source: Brong-Ahafo Chili Producer Survey; 2018-19.

Note: Legon 18 variety was the base category for the variety of long chili grown.

The age and sex of growers have no influence on prices. Fresh round chili producers whose place of origin is the district of production receive sale prices that are 19 percent higher than those who are not local. This result does not apply to dry long chili growers. Conversely, we find that dry long chili growers with some education earn 16 percent higher prices than dry long chili growers with no education at all. However, similar results are not found for fresh round chili growers.

Marketing choice effects are the driving factors of price determinants for both types of chilies, though in different directions. Selling at the market earns dry long chili growers 22 percent higher prices than selling at the farm gate, whereas farm gate sales give 30 percent higher prices than market sales to fresh round chili growers.

Each additional harvest of long chilies in the past year generates a 1.6 percent increase in the selling price of dry long chilies. However, we find no evidence for such a relationship in the fresh round chilies estimates.

There is a statistically significant association between the period in months from planting to the end of harvest and the price of chili. For dry long chilies, the maximum prices are obtained when 
the fresh crop is left in the ground for up to one year. In contrast, for round chilies, the statistical association between the length of time the crop is left in the field and the selling price is significant only at the $10 \%$ level and the highest price is obtained when chilies are left in the field for 8 months.

When we look at the coefficients for the marketing arrangement regressors, we find variation in their impact on prices across chili types. Increasing by one percentage point the share of fresh round chili growers who personally know traders buying in their community increases the price obtained by 30 percent, a very significant size effect. In contrast, this social network effect is not found to determine the price for dry long chilies. Increasing by one percentage point the share of dry long chili farmers who know the price others sold to traders increases the price they obtain by 12 percent, but it reduces by 24 percent the price obtained by fresh round chili growers. For the latter type of growers, the results also show that each additional trader who buys chilies in the community generates a 2 percent drop in the selling price. Moreover, when accounting for storage time of dry long chilies, the estimates suggest that every additional week of storage reduces the selling price by 16 percent.

Finally, we note that chili producers do not seem to face constraints in accessing markets. They are able to sell what they have produced, even if the prices may not be attractive to them. Only 4 percent of long chili producers - most of whom sold after drying - said they left some of their chilies unharvested because they felt there was no market. Fourteen percent of round chili producers - who sold them fresh - said they left some unharvested. These producers stated that, if they had better access to market, they could have harvested an average of an additional 4.7 bags per acre. Looking at the broader picture of Ghana's food crop value chains, chili producers appear to have better access to market compared to producers of pineapple, citrus, and mango.

Producers of these fruit crops indicated that they often do not harvest up to a third of their crop because they do not have buyers identified (Kolavalli et al. 2020).

\section{PRODUCER INCENTIVES}

\section{Profitability}

Despite low yields, vegetable production is profitable in Ghana. A survey done in 2017 showed that gross margins for tomato, onion, carrot, and Scotch bonnet chilis were high and much larger than the gross margins for staples, such as maize and rice (Van Asselt, Masias, and Kolavalli 2018). Gross margins from the cultivation of irrigated scotch Bonnet, for example, ranged from $\mathrm{GH} \phi 4,928 /$ ha in Tolon (Northern) to $\mathrm{GH} \phi 20,926 /$ ha in Kassena Nankana East (Upper East). Surveys by the International Water Management Institute in 2017 similarly showed high profits gross margins for Scotch bonnet farmers ranged from $\mathrm{GH} \phi 5,066 /$ ha on average in Bwaku West to $\mathrm{GH} \not 9,173 /$ ha in West Mamprusi. These are upper estimates because they are mostly for irrigated crops. In the Eastern region, farmers earned gross margins of around $\mathrm{GH} \phi 825$ per ha (Teye 2018). Saavedra Gonzalez et al. (2014) report that chili offers limited profitability compared to other export vegetables because it is produced with limited inputs, primarily labor. A case study of production for export found that farmers produce about 1,000 boxes (about $4,500 \mathrm{~kg}$ ) of chili pepper from an acre, which yields a revenue of about $\mathrm{GH} \phi 7,000$. Incurring costs of about $\mathrm{GH} \phi 5,000$ per acre, chili producers for export earn a margin of $\mathrm{GH} \phi 2,000$ per acre (about $\mathrm{GH} \phi$ 5,000 per ha).

Our estimate of gross margins earned by 621 producers of dry long chilies also suggests that they earn margins comparable to those obtained by producers of chili for export (Table 12). With a yield of 22 bags per ha ( 0.664 tons per ha), average gross margins were $\mathrm{GH} \phi 5,098$ per ha. The 
yields producers reported were close to the $775 \mathrm{~kg} / \mathrm{ha}$ observed by Teye (2018) and the $919 \mathrm{~kg} / \mathrm{ha}$ observed by Schippman (2006). Summing to nearly $\mathrm{GH} \phi 700$ per ha, the cost of labor (hired and exchange) accounts for nearly 70 percent of dry long chili production costs.

Table 12: Gross margins from production of dry long chilies, GHф per ha

\begin{tabular}{lr} 
Production components & $\begin{array}{r}\text { Costs, GH申 } \\
\text { per ha }\end{array}$ \\
Land preparation & 278 \\
a. Tractor & 61 \\
b. Labor & 216 \\
Seeds/seedlings & 32 \\
Planting (labor) & 111 \\
Plant protection & 45 \\
Fertilizer & 142 \\
$\quad$ a. Fertilizer & 119 \\
$\quad$ b. Labor for application & 22 \\
Irrigation & 3 \\
Weeding (labor) & 334 \\
Harvesting (labor) & 8 \\
Blanching and drying & 21 \\
\hline Total costs & 972 \\
\hline Gross revenues & 6,070 \\
$\quad$ a. Bags harvested per acre $(\mathrm{dry})$ & 22 \\
b. Average price received $(\mathrm{GH} \phi / \mathrm{bag})$ & 274 \\
\hline Gross margins per acre $(\mathrm{GH} \phi)$ & 5,098 \\
\hline Source: Brong-Ahafo Chill Producer Surey
\end{tabular}

Source: Brong-Ahafo Chili Producer Survey; 2018-19

\section{Trader margins}

Our evidence on who the traders buy from and to whom they sell suggests that the chili value chain from producers to consumers generally is short. Within Brong-Ahafo, at least three-quarters of traders buy at least some of the produce they trade directly from producers, either at the farm gate or at the markets to which the producers bring their produce. Three-quarters of the traders also indicate selling at least a portion of this produce to retail consumers. Although, the quantities that might go through various channels cannot be inferred from the data we have, the analysis suggests that a significant portion of the trade between producers and consumers takes place through only one intermediary trader. Only to a limited extent do traders aggregate chilies by buying from several producers to send to more distant larger consumer markets. Traders in larger markets, such as Kumasi and Accra, travel to distant production areas to buy directly from producers in most cases. Are producers better able to get a significant share of the price that consumer pay with so few intermediaries between them?

We cannot be conclusive on this on the basis of prices observed during the reconnaissance survey. Wholesale and retail prices-- wholesale prices being those paid by traders to producers or to other traders - observed in the selected markets on weekly market days were recorded over three weeks. The average, maximum, and minimum prices observed are presented in Appendix Table A2. Prices varied considerably among markets within Brong-Ahafo. Prices are not consistently higher in distant major markets, like Accra and Kumasi, than in the Brong-Ahafo region - major markets attract supplies from other producing areas as well.

Average prices are misleading because of their significant variation from day to day and by type of chili sold. Moreover, the units of measure used for exchange at various levels in the chili value chain are different. The measures used for trading in dry and fresh chilies and their conversion rates are presented in Table 13. Traders buy chilies from producers in larger woven bags or 
smaller rubbers (plastic bags), depending on the volume traded. They sell to each other using different measures. Wholesalers usually sell to retailers in woven bags or rubbers; retailers then sell in olonka or half olonka tins. Antwi and Matsui (2019) found that 44 percent of trade in one of the Brong-Ahafo markets was done using olonkas - typically empty margarine and tomato paste tins. These measures also vary from market to market. For example, a rubber may not be a standard 3.5 olonkas in all markets.

Table 13: Conversion of units of measure used along the chili value chain

\begin{tabular}{lcc}
\multicolumn{1}{c}{ Units } & \multicolumn{1}{c}{ Fresh chili } & Dried chili \\
Black rubber & 8 per size 4 woven bag & 10 per size 4 woven bag \\
Olonka & 3.5 per rubber & 5 per rubber \\
& & Weight \\
Size 4 woven bag & $80 \mathrm{lb} .(36.4 \mathrm{~kg})$ & $65 \mathrm{lb} .(29.5 \mathrm{~kg})$ \\
Black rubber & $10 \mathrm{lb} .(4.5 \mathrm{~kg})$ & $6.5 \mathrm{lb} .(2.9 \mathrm{~kg})$ \\
Olonka & $3.6 \mathrm{lb} .(1.6 \mathrm{~kg})$ & $2.2 \mathrm{lb} .(1.0 \mathrm{~kg}$ \\
\hline
\end{tabular}

Source: Fieldwork

We examined purchase and sale prices and measures reported used by traders for their last completed transaction. Table 14 reports on who made them, whether wholesaler or retailer; the combination of measures used in buying and selling; and where in the value chain the transaction took place. Margins have been estimated using the conversion rates in Table 13 wherever buying and selling measures were different.

Although the evidence is limited to a small sample of respondents for which data on full transactions was collected, so does not allow generalizing our results, the figures provide some interesting and intuitive observations:

- Wholesalers make smaller margins than retailers.

- Margins are likely to be smaller when buying and selling is done using the same measure. Despite the limited number of observations, Table 14 shows that buying and selling in either bags or rubbers is associated with smaller margins. By breaking larger units of chilies into smaller units, retailers earn higher margins.

- While there are some exceptions, margins tend to be lower at higher prices. 
Table 14: Prices and margins in selected dry long chili transactions reported by traders, grouped by quantity unit conversion in transaction

\begin{tabular}{|c|c|c|c|c|c|}
\hline \multicolumn{6}{|l|}{ Quantity unit conversion } \\
\hline \multicolumn{3}{|c|}{ Wholesalers } & \multicolumn{3}{|l|}{ Retailers } \\
\hline $\begin{array}{l}\text { Purchased from and } \\
\text { sold to }\end{array}$ & $\begin{array}{l}\text { price, } \mathbf{G H} \phi / \\
\text { original unit }\end{array}$ & $\underset{\%}{\operatorname{margin}}$ & $\begin{array}{l}\text { Purchased from } \\
\text { and sold to }\end{array}$ & $\begin{array}{l}\text { price, } \mathbf{G H} \phi / \\
\text { original unit }\end{array}$ & $\underset{\%}{\operatorname{margin}}$ \\
\hline \multicolumn{6}{|l|}{ Woven bag to woven bag } \\
\hline Farm gate purchase to retailer & 50 & 60 & Wholesaler to consumers & 120 & 25 \\
\hline $\begin{array}{l}\text { Market purchase from producer } \\
\text { to retailer }\end{array}$ & 250 & 20 & $\begin{array}{l}\text { Wholesaler selling produce from } \\
\text { outside of region to consumer }\end{array}$ & 120 & 25 \\
\hline \multicolumn{6}{|l|}{ Woven bag to rubber } \\
\hline Farm gate purchase to retailer & 180 & 33 & $\begin{array}{l}\text { Market purchase from producer } \\
\text { to consumers }\end{array}$ & $100-120$ & 100 \\
\hline \multirow[t]{2}{*}{$\begin{array}{l}\text { Market purchase from producer } \\
\text { to retailer }\end{array}$} & 130 & 85 & Wholesaler to consumers & $\begin{array}{l}110 \\
200 \\
550\end{array}$ & $\begin{array}{r}120 \\
60 \\
0\end{array}$ \\
\hline & & & $\begin{array}{l}\text { Wholesaler selling produce from } \\
\text { outside of region to consumer }\end{array}$ & 80 & 150 \\
\hline \multicolumn{6}{|l|}{ Woven bag to olonka } \\
\hline \multirow[t]{4}{*}{ (No observations) } & & & Farm gate purchase to consumer & $\begin{array}{l}100 \\
500\end{array}$ & $\begin{array}{c}140 \\
1,120\end{array}$ \\
\hline & & & $\begin{array}{l}\text { Market purchase from producer } \\
\text { to consumers }\end{array}$ & 150 & 30 \\
\hline & & & Wholesaler to consumers & $\begin{array}{l}100 \\
150 \\
200 \\
300\end{array}$ & $\begin{array}{l}180 \\
140 \\
280 \\
366\end{array}$ \\
\hline & & & $\begin{array}{l}\text { Wholesaler selling produce from } \\
\text { outside of region to consumer }\end{array}$ & 100 & 40 \\
\hline \multicolumn{6}{|l|}{ Rubber to rubber } \\
\hline \multirow{2}{*}{$\begin{array}{l}\text { Market purchase from producer } \\
\text { to retailer }\end{array}$} & 20 & 25 & Wholesaler to consumers & 20 & 25 \\
\hline & & & $\begin{array}{l}\text { Wholesaler selling produce from } \\
\text { outside of region to consumer }\end{array}$ & 20 & 50 \\
\hline \multicolumn{6}{|l|}{ Rubber to olonka } \\
\hline \multirow[t]{3}{*}{$\begin{array}{l}\text { Market purchase from producer } \\
\text { to retailer }\end{array}$} & 50 & -2 & $\begin{array}{l}\text { Market purchase from producer } \\
\text { to consumers }\end{array}$ & $\begin{array}{l}15 \\
20 \\
25 \\
50 \\
60\end{array}$ & $\begin{array}{r}133 \\
75 \\
124 \\
12 \\
20\end{array}$ \\
\hline & & & Wholesaler to consumers & $\begin{array}{l}20 \\
30 \\
40 \\
55 \\
65\end{array}$ & $\begin{array}{r}40 \\
40 \\
162 \\
90 \\
8\end{array}$ \\
\hline & & & $\begin{array}{l}\text { Wholesaler selling produce from } \\
\text { outside of region to consumer }\end{array}$ & $\begin{array}{l}25 \\
30\end{array}$ & $\begin{array}{l}40 \\
70\end{array}$ \\
\hline
\end{tabular}

Source: Trader survey

\section{SUMMARY}

Chili is an attractive cash crop which is predominantly cultivated by smallholders in Ghana. For producers in Brong-Ahafo, who cultivate chilies under rainfed conditions, it is a low input-low output, yet relatively profitable crop. With gross margins in excess of $\mathrm{GH} \phi 5,000$ per acre, it compares favorably with other crops.

Chili yields are less than $1.0 \mathrm{mt} / \mathrm{ha}$, while research data suggests chilies have a yield potential in Ghana of nearly $8 \mathrm{mt} / \mathrm{ha}$. So, there is considerable room for improving yields. While long chili growers harvested an average of 11 bags per acre, growers in the top 10 percentile by yields 
harvested close to 18 bags. These higher yields were obtained primarily by applying higher levels of inorganic fertilizers.

Producers are doing a better job of adopting improved chili varieties. Nearly 70 percent of the long chili producers had planted Legon 18, a variety released by the Ghana agricultural research system that generally is processed into chili powder.

Producers keep their crop in the field for unusually long periods. Those doing so do not seem to harvest more, but they are able to get better prices. Perhaps, they obtain higher average prices by extending their production into leaner production periods or making more forays into the market.

Fresh and dry chilies are marketed differently. Nearly 80 percent of dry chili producers sell at the farm gate and obtain prices higher than those producers who take their dry chilies to markets. The reverse is true for fresh chili producers. One plausible explanation is that, without being certain that there will be adequate number of buyers at the marketplace, producers choose to have committed buyers come to them. Fresh round chili producers, on the other hand, are forced to take the produce to market when it is ready for harvest. Fresh chili producers that are natives of their community or have strong marketing networks also obtain higher prices than others. It is plausible that producers choose between producing dry long or fresh round chilies depending on their marketing ability. 


\section{REFERENCES}

Antwi, A. O., and K. Matsui. 2019. "Price perception on weights and measures at the local markets of Ghana." Kasetsart Journal of Social Sciences, 40: 552-557.

Asare-Bediako, E., A. Addo-Quaye, B. Boakye, J. M. Sarbah, P. Asante, and E. Dorm. 2015. "Incidence and severity of viral and fungal diseases of chili pepper (Capsicum frutescens) in some districts in Ghana." International Journal of Plant \& Soil Science. 7(3): 147-159.

DAI and Nathan Association Inc. 2014. Chili market diagnostics: DFID Market Development (MADE) in Northern Ghana Programme. Department for International Development, Ghana.

GSS (Ghana Statistical Service). 2014. Ghana Living Standards Survey Report of the Sixth Round (GLSS 6). Accra: Ghana Statistical Service.

GSS (Ghana Statistical Service). 2013. 2010 Population \& Housing Census: National Analytical Report. Accra: Ghana Statistical Service.

Kolavalli, S., J. Agandin, A. Ampofo, F. Kemeze, and S. Amewu. 2020. Value chain development to benefit smallholders in Ghana: The effectiveness of selected interventions. Ghana Strategy Support Program Working Paper 51. Washington, DC: International Food Policy Research Institute.

MiDA (Millennium Development Authority). 2010. Investment opportunity in Ghana: Chili pepper. Millennium Development Authority, Accra, Ghana. 2010; 1-25. Accessed 28th February 2014. https://www.mcc.gov/documents/ investmentopps/bom-ghana-englishchili.pdf

MoFA (Ministry of Food and Agriculture) 2015. Agriculture in Ghana: Facts and Figures (2014). Statistics, Research and Information Directorate (SRID). Accra: Ministry of Food and Agriculture.

MoFA (Ministry of Food and Agriculture) 2014. Agriculture in Ghana: Facts and Figures (2013). Statistics, Research and Information Directorate (SRID). Accra: Ministry of Food and Agriculture.

Nkansah, G.O., A. Ayarna and T.J. Gbokie. 2011. "Morphological and yield evaluation of some Capsicum pepper line in two agro-ecological zones of Ghana. Journal of Agronomy 10 (3): 84-91.

Pingali P., A. Anaka, M. Abraham, and R. Andaleeb. 2019. Transforming Food Systems for a Rising India. New York: Palgrave Macmillan.

Quartey, E.K., W. Nekpeku, M. Owusu-Ansah, A.S. Appiah, E.S.K. Ofori, and H.M. Amoate. 2014. "Agronomic evaluation of eight genotypes of hot pepper (Capsicum spp. L.) in the coastal savanna zone of Ghana," Journal of Biology, Agriculture and Healthcare. 4 (24): 16.

Saavedra Gonzalez, Y.R., Y. Dijkxhoorn, P. Obeng, and P. Schotel. 2014. Ghana Export Vegetable Chain; Identifying opportunities for development. Centre for Development Innovation, Wageningen UR. Report CDI-14-021. Wageningen, The Netherlands: Wageningen UR.

Schippman, C. 2006. Value chains for a better integration of smallholders to trade - The case of chili in Ghana. MSc Thesis Department of Agricultural Economics. Humboldt-University Berlin.

Teye, N.K. 2018. Production and marketing prospects of chili pepper in the Upper Manya District, Ghana. MSc Thesis. Department of Horticulture, Faculty of Agriculture, University for Development Studies, Tamale.

Van Asselt, J., I. Masias, and S. Kolavalli. 2018. Competitiveness of the Ghanaian vegetable sector: Findings from a farmer survey. Ghana Strategy Support Program Working Paper 47. Washington, DC: International Food Policy Research Institute. 


\section{APPENDIX}

Table A1: Number of chili traders reported by producers to be operating in the communities surveyed

\begin{tabular}{|c|c|c|c|c|c|}
\hline \multicolumn{6}{|c|}{ In the last 12 months, how many agents/traders purchased chili in this community? } \\
\hline District & Community & Observations & Minimum & Mean & Maximum \\
\hline \multirow[t]{3}{*}{ Atebubu Amantin } & Mem & 41 & 0 & 7 & 20 \\
\hline & Atebubu & 70 & 0 & 28 & 100 \\
\hline & Kokofu & 24 & 0 & 8 & 20 \\
\hline \multirow[t]{3}{*}{ Berekum Municipal } & Fetentaa & 26 & 0 & 6 & 15 \\
\hline & Jinijini & 16 & 0 & 7 & 10 \\
\hline & Namasua & 34 & 0 & 5 & 10 \\
\hline \multirow[t]{4}{*}{ Dormaa Municipal } & Aboabo No.2 & 13 & 3 & 7 & 20 \\
\hline & Kwameasua & 18 & 0 & 7 & 15 \\
\hline & Amansu & 13 & 5 & 11 & 20 \\
\hline & Asunsu No. 2 & 12 & 2 & 7 & 10 \\
\hline \multirow[t]{4}{*}{ Jaman North } & Asantekrom & 47 & 0 & 5 & 10 \\
\hline & Old Drobo & 21 & 2 & 5 & 10 \\
\hline & Duadaso & 5 & 4 & 4 & 5 \\
\hline & Seketia & 27 & 2 & 8 & 30 \\
\hline \multirow[t]{6}{*}{ Jaman South } & Faaman/Boadwo & 20 & 1 & 5 & 20 \\
\hline & Kojokesekrom & 7 & 0 & 3 & 7 \\
\hline & Atuna & 16 & 1 & 6 & 25 \\
\hline & Tainano No.1 & 10 & 2 & 5 & 8 \\
\hline & Tainano No.2 & 23 & 0 & 5 & 10 \\
\hline & Kofiko & 16 & 1 & 5 & 8 \\
\hline \multirow[t]{3}{*}{ Pru } & Adjentriwa & 45 & 0 & 3 & 10 \\
\hline & Abua & 48 & 0 & 3 & 10 \\
\hline & Abease & 40 & 0 & 5 & 15 \\
\hline \multirow[t]{2}{*}{ Sene East } & CFAO Quarters & 22 & 0 & 0 & 0 \\
\hline & Akruka & 35 & 0 & 7 & 14 \\
\hline \multirow[t]{2}{*}{ Sunyani West } & Abronye & 20 & 1 & 4 & 30 \\
\hline & Adentire & 20 & 1 & 9 & 20 \\
\hline \multirow[t]{7}{*}{ Tain } & Badu-Drobo & 15 & 2 & 5 & 8 \\
\hline & Kyekyewere & 24 & 0 & 4 & 10 \\
\hline & Menji & 9 & 5 & 7 & 9 \\
\hline & Kwame Tenten & 7 & 0 & 3 & 5 \\
\hline & Abekwae No. 2 & 7 & 0 & 2 & 3 \\
\hline & Kolongo & 14 & 0 & 0 & 0 \\
\hline & Hani & 9 & 5 & 8 & 15 \\
\hline \multirow[t]{3}{*}{ Tano South } & Old Brosankro & 5 & 0 & 3 & 8 \\
\hline & Konkombaline & 18 & 0 & 11 & 20 \\
\hline & Adaa & 16 & 2 & 10 & 20 \\
\hline \multirow[t]{2}{*}{ Techiman Municipal } & New Techiman & 55 & 0 & 6 & 30 \\
\hline & Nkwaeso & 24 & 1 & 3 & 6 \\
\hline \multirow[t]{3}{*}{ Asutifi North } & Ntotroso & 5 & 3 & 7 & 10 \\
\hline & Goamu Camp & 19 & 0 & 1 & 10 \\
\hline & Goamu Atwedie & 12 & 1 & 4 & 6 \\
\hline \multirow[t]{3}{*}{ Asutifi South } & Hwidem & 14 & 3 & 11 & 20 \\
\hline & Kokofo & 7 & 1 & 5 & 8 \\
\hline & Ata ne ata & 10 & 0 & 3 & 6 \\
\hline Overall & & 959 & & 7 & \\
\hline
\end{tabular}

Source: Brong-Ahafo Chili Producer Survey; 2018-19. 
Table A2: Wholesale and retail prices per bag observed over three weeks in selected markets.

\begin{tabular}{|c|c|c|c|c|c|c|c|c|c|}
\hline \multirow[t]{3}{*}{ Chili types } & \multicolumn{3}{|c|}{ Brong-Ahafo ${ }^{1}$} & \multicolumn{3}{|c|}{ Northern region ${ }^{2}$} & \multirow[t]{2}{*}{ Ho } & \multirow[t]{2}{*}{ Accra } & \multirow[t]{2}{*}{ Kumasi } \\
\hline & \multicolumn{6}{|c|}{ Wholesale prices } & & & \\
\hline & Min & Max & Avg. & Min. & Max. & Avg. & Avg. & Avg. & Avg. \\
\hline Green Scotch bonnet & 150 & 243 & 192 & 190 & 216 & 205 & 207 & 309 & 335 \\
\hline Red Scotch bonnet & 187 & 415 & 271 & 152 & 214 & 174 & 236 & 484 & 299 \\
\hline Green long chili & NA & NA & NA & 195 & 195 & 195 & 280 & NA & NA \\
\hline Red long chili & NA & NA & NA & 221 & 221 & 221 & 215 & 0.00 & 0.00 \\
\hline Dried Scotch bonnet & 300 & 300 & 300 & 213 & 400 & 306 & NA & 375 & 0.00 \\
\hline Dried long chili & 255 & 472 & 376 & 209 & 479 & 344 & 355 & 333 & 259 \\
\hline \multicolumn{10}{|c|}{ Retail prices } \\
\hline Green Scotch bonnet & 180 & 277 & 238 & 162 & 220 & 190 & 288 & 328 & 275 \\
\hline Green Scotch bonnet & 229 & 410 & 303 & 128 & 238 & 172 & 275 & 431 & 244 \\
\hline Red Scotch bonnet & NA & NA & NA & 200 & 750 & 475 & NA & NA & NA \\
\hline Green long chili & NA & NA & NA & 214 & 214 & 214 & 457 & 0.00 & 0.00 \\
\hline Red long chili & 240 & 468 & 358 & 209 & 450 & 359 & NA & NA & NA \\
\hline Dried Scotch bonnet & 247 & 371 & 310 & 209 & 556 & 405 & 420 & 414 & 203 \\
\hline
\end{tabular}

Source: Brong-Ahafo Chili Producer Reconnaissance Survey; 2018

Note: NA = 'not applicable'

${ }_{1}^{1}$ Average prices observed in ten markets in Brong-Ahafo.

${ }^{2}$ Average of prices observed in three northern markets: Novrongo, Tamale, and Bolga. 


\section{ABOUT THE AUTHORS}

Marcella Vigneri is research fellow at the Centre of Excellence in Impact Evaluation and Learning, based at the London School of Hygiene and Tropical Medicine in the United Kingdom.

Shashi Kolavalli is an independent researcher based in Vienna, Virginia, USA. John Agandin at the time of this study was a Research Officer in the Ghana Strategy Support Program (GSSP) of the International Food Policy Research Institute (IFPRI), based in Accra. Qondi Moyo at the time of this study was a consultant to GSSP of IFPRI, based in Accra.

\section{ACKNOWLEDGMENTS}

The authors gratefully acknowledge the funding support from the United States Agency for International Development (USAID) and the CGIAR Research Program on Policies, Institutions and Markets (PIM).

We are grateful to Dr. Cyril T. Quist, then regional Director of Agriculture, and his fellow staff at the Brong Ahafo Regional Office of the Ministry of Food and Agriculture (MOFA). These MoFA colleagues kindly made available their offices for our meetings and trainings, provided us with information on chili production across Brong Ahafo, and shared contact details of district staff for the fieldwork for this study. We are also grateful to Mr. Kwame Adjei, managing director of EKA Food Processing Company Ltd, Sunyani, and the management of the Asutifi Processing \& Services Centre, Hwidiem, who gave us useful insights into the chili value chain. We acknowledge the farmers, traders, and numerous other stakeholders we interviewed who made time to share insights and experiences with us. We thank Todd Benson for his review of this Working Paper.

The views expressed are those of the authors and do not necessarily reflect those of any funding partners or the authors' employers.

INTERNATIONAL FOOD POLICY RESEARCH INSTITUTE 1201 Eye St, NW | Washington, DC 20005 USA T. +1-202-862-5600 | F. +1-202-862-5606 Email: ifpri@cgiar.org | www.ifpri.org | www.ifpri.info
IFPRI-ACCRA

c/o IWMI, PMB CT 112; Cantonments, Accra, Ghana CSIR Campus (Opposite Chinese Embassy), Airport Residential Area T. +233 (0) 302780716 | F. +233 (0) 302784752 | gssp.ifpri.info 